\title{
CHEMICAL COMPOSITION AND SALT LOAD IN RAINWATER OF MOSUL CITY-NINEVEH GOVERNORATE
}

\author{
Amer W. Abdul-Kareem \\ M.T. S. Khalil \\ K.E. AL-Hadidi \\ Soil Sciences and Water Resources Dept., College of Agriculture and Forestry, Mosul University. Iraq \\ E-mail:amer-waddie@yahoo.com
}

\begin{abstract}
The present study reports the chemical composition and atmospheric salt load rainwater of Mosul city/ Nineveh Governorate / Iraq. The sampling were done from October 2012 to March 2013. Twenty six samples were collected and analyzed for $\mathrm{pH}$, ion concentration $\left(\mathrm{Ca}^{++}, \mathrm{Mg}^{++}, \mathrm{K}^{+}, \mathrm{Na}^{+}, \mathrm{CI}^{-}, \mathrm{HCO}_{3}^{-}, \mathrm{SO}_{4}^{--}\right)$and electrical conductivity. Total rainwater was $338.55 \mathrm{~mm}$. The results show that the volume weighted mean (VWM) pH and electrical conductivity in the rainwater were 6.83 and $114.22 \mu \mathrm{S} \mathrm{cm}^{-1}$ respectively. Cation and anion concentration took the following order : $\mathrm{Ca}^{++}>\mathrm{Mg}^{++}>\mathrm{Na}^{+}>\mathrm{K}^{+}$and $\mathrm{HCO}_{3}{ }^{-}>\mathrm{CI}^{-}>\mathrm{SO}_{4}{ }^{2}$. $\mathrm{HCO}_{3}{ }^{-}$and $\mathrm{Ca}^{++}$contributed $65.3 \%$ of the total ions in the rainwater. Equivalents ratios for different ionic components to sodium, revealed higher values in rainwater than that of seawater. This indicates the dominance of non-marine in studied samples. Analyses revealed that loads delivered from the fallen precipitation in the urban city of Mosul was about $0.1167 \mathrm{~kg} \mathrm{cl}^{-} / \mathrm{m}^{3}$ of chloride in rainwater which equal numerically to $395 \mathrm{~kg} \mathrm{NaCI} . \mathrm{h}^{-1}$ of land.
\end{abstract}

Keywords: rainwater, conductivity, $\mathrm{pH}$, volume weighted mean, $\mathrm{EF}$.

Received: 3/9/2013, Accepted: 17/2/2014.

\section{INTRODUCTION}

In meteorology, precipitation is any product of the condensation of atmospheric water vapor that falls under gravity (Tolgyessy,1993). The main forms of precipitation include drizzle, rain, sleet, snow, grapple and hail. Precipitation occurs when a local portion of the atmosphere becomes saturated with water vapor, so that the water condenses and precipitates . It is a major component of the water cycle (Nicolae and Cotet,2012), and it responsible for depositing the fresh water on the planet. Approximately $505,000 \mathrm{~km}^{3}$ of water falls as precipitation each year; $398,000 \mathrm{~km}^{3}$ of it over the oceans and $107,000 \mathrm{~km}^{3}$ over land .The partition of atmospheric water is $0.001 \%$ and $0.04 \%$ of total and fresh water respectively (Ghassemi,etal.,1995). Raindrops have sizes ranging from (0.1-9.0) $\mathrm{mm}$ in diameter, above which they tend to break up. The atmospheric water vapor is the most abundant form of pure natural water, however, it becomes polluted when passes through the air layers, and it washout considerable quantities of aerosols from air which is the most important sources of continental dust ,salts carried by wind from the surface of seas, surface rivers, volcanic and anthropogenic activities (Radojevic and Bashkin,2006). Apart of these affects on chemical composition of rainfall are varies from region to region, depending on on water content in clouds, quantity and duration of precipitation, size of droplets and intensity of rainfall (Sillapapiromsuk and Chantara,2010). Therefore the processes controlling the composition of rain are complex and influenced by both natural and anthropogenic sources. If the source is influenced by increasing man made activities, the rainwater will become acid because the anthropogenic activities contribute acidic gases like $\mathrm{SO}_{4}$ and $\mathrm{NO}_{3}$ and basic gases like $\mathrm{NH}_{3}$ (Kulshrestha et al.,2003). The aim of this paper is to obtain an initial understanding of rainfall chemistry, including its composition and salt load at an urban locality in the center of Mosul, capital of Nineveh Governorate, due to non availability of these data. 


\section{MATERIALS AND METHODS}

Sampling site : The sampling site located at an urban location in Mosul, the center of Mosul city and provincial capital of Nineveh which lies across the Tigris river on the right side of ancient Nineveh $\left(36^{\circ} 0^{\prime} \mathrm{N} 42^{\circ} 28^{\prime} \mathrm{E}\right)$. Mosul has an area of 37,323 square kilometers $(14,410$ sq mile).

Sampling and analysis: Although rainwater analysis may appear to be fairly straightforward, but it is in fact quite problematic because of the low concentrations of ions present . Therefore, great care must be taken during handling, storing and analyzing samples in order to maintain sample integrity from pollution. Rainwater samples were collected continuously after each rainfall from October 2012 to the end of March 2013 using a clean container of $32 \mathrm{~cm}$ in diameter. The volume of the sample was measured and divided by the cross sectional area of the container to obtain the depth of the atmospheric precipitation. The samples were filtered to remove particulate matter and sediment and rainwater samples were stored in a refrigerator at $4{ }^{\circ} \mathrm{C}$ until analysis. Each sample was analyzed for $\mathrm{pH}$ and conductivity immediately using a conductivity and $\mathrm{pH}$ meter (Type : JENWAY $3540 \mathrm{pH} \&$ Conductivity meter). Samples were analyzed for cations $\left(\mathrm{K}^{+}, \mathrm{Mg}^{2+}, \mathrm{Na}^{+}\right.$andCa $\left.{ }^{2+}\right)$ and anions $\left(\mathrm{Cl}^{-}, \mathrm{HCO}_{3}^{-}\right.$ and $\mathrm{SO}_{4}{ }^{2-}$ ) according to methods outlined by (Tandon ,1999). In rainwater surveys, the common practice to calculate the volume weighted mean (VWM) of ionic concentrations rather than the arithmetic average because it takes into account dilution effect by the rainfall amount (Oliveira et al.,2012). The VWM can be calculated from: VWM of $\mathrm{X}=\sum\left(\left[\mathrm{X}_{\mathrm{i}}\right] \times \mathrm{R}_{\mathrm{i}}\right) / \sum \mathrm{R}_{\mathrm{i}}$. Where $\left[\mathrm{X}_{\mathrm{i}}\right]$ is the concentration of substance $\mathrm{X}, \mathrm{R}_{\mathrm{i}}$ is the rainfall amount . To account for rainfall uniformity, precipitation concentration index (PCI) was calculated from: $\mathrm{PCI}=100 \sum \mathrm{Pi}^{2} / \mathrm{P}^{2}$, where $\mathrm{pi}=$ monthly precipitation and $\mathrm{p}=$ annual precipitation. According to Valli et al.,(2013), PCI $<10$ indicates uniform precipitation and PCI > 20 indicates a strong irregularity (i.e., high precipitation concentration). Enrichment factor (EF) for different ionic components with respect to sodium was also estimated and considered as effective tool to assess the origin of salts in rainwater and was estimated according to (Tiwari et al.,2006) by the following equation :

$$
\mathrm{EF}=\left[\mathrm{X} / \mathrm{Na}^{+}\right]_{\text {rainwater }} /\left[\mathrm{X} / \mathrm{Na}^{+}\right]_{\text {seawater }} \text { Where }\left[\mathrm{X} / \mathrm{Na}^{+}\right]_{\text {rain }} \text { and }\left[\mathrm{X} / \mathrm{Na}^{+}\right]_{\text {seawater }} \text { are }
$$

the mass ratios of ion $\mathrm{X}$ relative to sodium in rain and seawater respectively. An EF approaching to unity suggests that the ion is originated from sea-salt (no enriched elements), whereas an EF greater than unity suggests that a significant portion of the ion has origin in a source different than sea-salt (enriched elements).

\section{RESULTS AND DISCUSSION}

1-Rain quantity : A total of 26 rainwater samples were collected continuously. The largest number of rainfall along with precipitation depths were observed in January (6) $(25,6.25$, $24.38,37.75,22.88,17.75) \mathrm{mm}$ and in February (6) $(5.25,21.88,7.98,3.6,1.5,18.88) \mathrm{mm}$ followed by November (5) $(2.4,5.8,5.9,19,22.5) \mathrm{mm}$ and December (5) $(1.9,2.9,10,13.75$, $23.75) \mathrm{mm}$, March (3) $(3.75,22.5,4.88) \mathrm{mm}$ and only one rainfall was present in October with a $6.75 \mathrm{~mm}$ depth. Monthly rainwater during the study period is presented in Figure1. The largest number of monthly events occurred in January with the highest rainfall $(134 \mathrm{~mm})$ followed by February $(59 \mathrm{~mm})$, November $(55.5 \mathrm{~mm})$, December $(52.3 \mathrm{~mm})$, March $(31 \mathrm{~mm})$ and October(6.75mm). The months of April, May, June, July, August and September are considered as dry season. The Precipitation Concentration Index (PCI) value for the urban studied area of Mosul indicate highly irregular distribution of rainfall (24.7\%) as outlined by Valli et al.,(2013). 


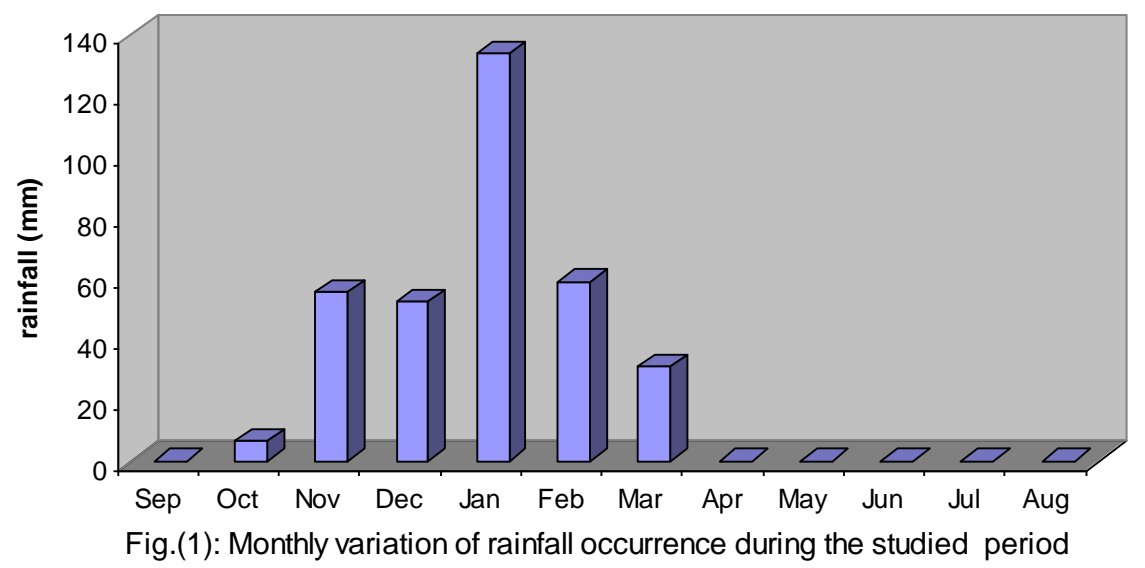

2- Variation of $\mathbf{p H}$ : The $\mathrm{pH}$ of natural rainwater is controlled by dissolved $\mathrm{CO}_{2}$ due to the interaction between water droplets and carbon dioxide. It varies between 3 and 9, but generally having ranged between 4 and 6 . Rainwater $\mathrm{pH}$ is modified by addition of both acidic and alkaline components (Topcu and Atimtay, 2002: Singh and Mondal,2008). Fig.2 shows the temporal variation of volume weighted $\mathrm{pH}$ with a mean of 6.5 for the urban city of Mosul which is greater than the $\mathrm{pH}$ value of unpolluted rainwater at equilibrium with atmospheric $\mathrm{CO}_{2}$. It seems that in the dry month, high amounts of alkaline dust accumulated in the atmosphere due to human activities and low levels of precipitation, accordingly, rain samples collected contain high ionic concentrations, which presented low $\mathrm{pH}$ values . Monthly VWM pH were lowest in January (6.21) and highest in March (7.66). Alkaline rainwater has been reported in different parts of the world . In India ,Chandra et al., (2005) reported an alkaline VWM pH (6.78).In another study, in the urban area of Ankara, Turkey, reported alkaline $\mathrm{pH}$ values due to high calcium carbonate loading from soil (Topcu et al.,2002).

3- Electrical conductivity measurements: The EC of rainwater is mainly attributed to the total soluble ionic components present in the rainwater samples which reflect the impact of atmospheric particulate matter on the rainwater chemistry. The mean of electrical conductivity values were $152.1 \pm 126.4 \mu \mathrm{S} . \mathrm{cm}^{-1}$. The results showed higher dispersion around their mean values according to the standard deviation. Depending on rain event basis, EC values ranged from 5.16-600 $\mu{\mathrm{S} . \mathrm{cm}^{-1}}$ for all the rainwater samples and from $91.3-300 \mu \mathrm{S}^{-1} \mathrm{~m}^{-1}$ on a monthly basis. For calculating VWM of the EC values, it must first converted to concentration (TDS), it was found to be $114.22 \mathrm{mg} . \mathrm{l}^{-1}$. Irrespective of rain quantity, March recorded the highest mean EC values whereas the month with the lowest value was October (Fig.3), .In January relying on EC with rain quantity, based on the dilution effect, the amount of precipitation is inversely related to the EC values.

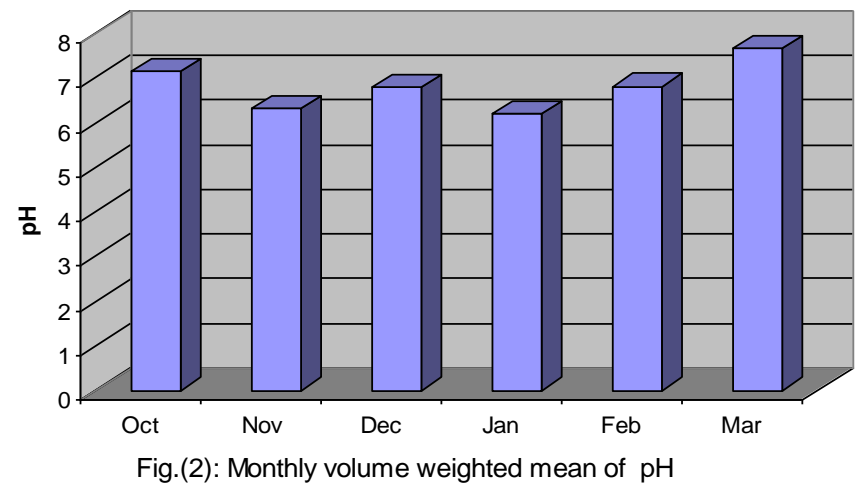




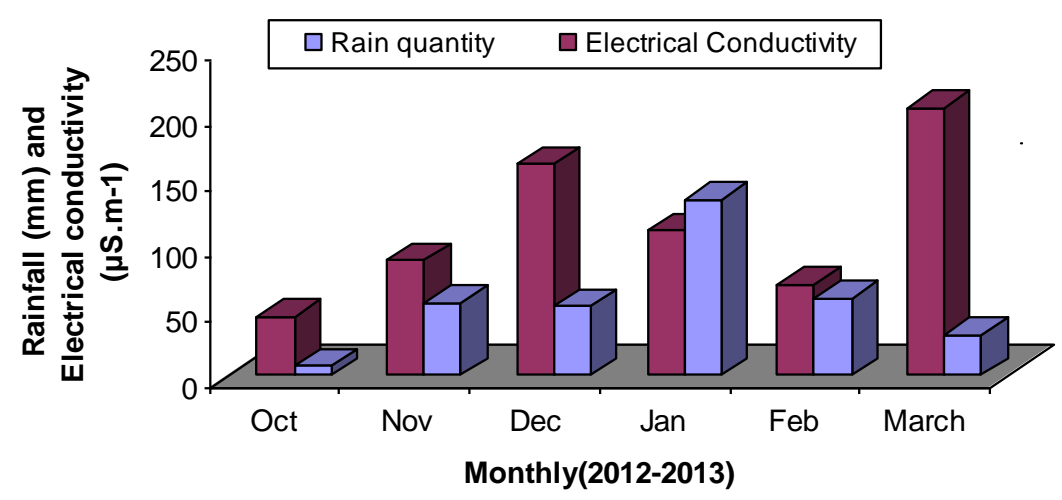

Fig.(3):Variation in monthly precipitation amount and VWM of electrical conductivity

4- Ionic composition of rainwater: Table(1) shows the mean, minimum and maximum values, standard deviation of measured ions and volume weighted mean(VWM) concentration $(\mu \mathrm{eq} / \mathrm{l})$ of various chemical constituents of rainwater collected along the studied period. Cation and anion concentration decreased respectively, according to the following sequences : $\mathrm{Ca}^{++}>\mathrm{Mg}^{++}>\mathrm{Na}^{+}>\mathrm{K}^{+}$and $\mathrm{HCO}_{3}{ }^{-}>\mathrm{CI}^{-}>\mathrm{SO}_{4}{ }^{=}$. Volume weighted mean concentration of ions take the same order with values ranging from 2800 to $82.5 \mu \mathrm{eq} / \mathrm{I}$ for cations, and from 2800 to $400 \mu \mathrm{eq} / \mathrm{I}$ for anions. Although the study revealed greater variation in monthly mean concentration of major ions in rainwater, but the higher concentration of chemical species especially calcium, chloride and bicarbonate were associated with small volume of rainwater and vice versa (Chandra et al., 2005). Figure(4) describes the percentage contribution of each ionic constituent to total ionic mass. Among the anions the dominant species was bicarbonate contributing $70 \%$ and $37.7 \%$ to the total ionic composition. This was followed by $\mathrm{CI}^{-}(8.1 \%)$ and sulphate $(7.7 \%)$. In cation category $\mathrm{Ca}^{++}$ was dominant contributing $59 \%$ of the total cations and $27.6 \%$ of the total ionic content in the rainwater samples. This was followed by $\mathrm{Mg}^{++}(16.1 \%)$, sodium $(2.2 \%)$ with very low contribution of $\mathrm{K}^{+}(0.6 \%)$ to the total ionic mass. The alkaline components measured in rainwater were, $\mathrm{Ca}^{++}, \mathrm{Mg}^{++}, \mathrm{Na}^{+}$and $\mathrm{K}^{+}$contribute about $46.6 \%$ of the total concentration , where the acidic components comprising of $\mathrm{SO}_{4}{ }^{2}, \mathrm{CI}^{-}$and $\mathrm{HCO}_{3}{ }^{-}$make up 53.4\%. As the soils in Iraq are calcareous and contain between 15-35\% calcium carbonate (Anonymous, 1977), therefore, the presence of both $\mathrm{HCO}_{3}{ }^{-}$and $\mathrm{Ca}^{++}$in the precipitation are natural and act as sources of carbonate-rich soil/dust particles and were responsible for $65.3 \%$ of the total ions in the rainwater. The elevated levels of dust storms in Mosul in recent years due to desertification caused by shortage of precipitation led to re-suspending dust from soil into the atmosphere and the intensive building activities involving the use of cement within the urban city of Mosul.

Table (1): $\mathrm{pH}$ and major ion chemistry( $\mu \mathrm{eq} / \mathrm{L})$ (volume weighted) of rainwater over

\begin{tabular}{|c|c|c|c|c|}
\hline Parameter & Min & Max & Mean \pm SD & VWM \\
\hline $\mathrm{pH}$ & 6.21 & 7.66 & $7.01 \pm 0.53$ & 6.83 \\
\hline $\mathrm{Na}^{+}$ & 9.5 & 188.05 & $100.6 \pm 61.01$ & 90.9 \\
\hline $\mathrm{K}^{+}$ & 5.8 & 82.50 & $33.6 \pm 29.43$ & 26.1 \\
\hline $\mathrm{Ca}^{++}$ & 499.4 & 2800 & $1390 \pm 794.0$ & 1132.5 \\
\hline $\mathrm{Mg}^{++}$ & 229.8 & 1486.3 & $673.2 \pm 448.7$ & 659.4 \\
\hline $\mathrm{CI}^{-}$ & 285.6 & 400 & $332.3 \pm 319.1$ & 333.0 \\
\hline $\mathrm{SO}^{-}$ & 42.7 & 904.8 & $350.6 \pm 337.7$ & 316.6 \\
\hline $\mathrm{HCO}^{-}$ & 907 & 2800 & $1689 \pm 670.0$ & 1545.1 \\
\hline
\end{tabular}




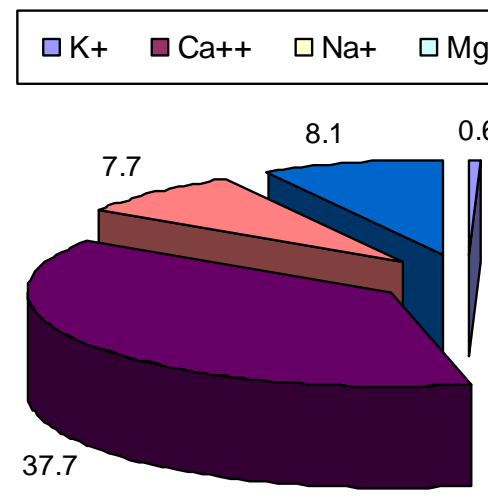

0.6

Fig.(4): Percentage contribution of each ion to total ionic mass

5- Marine contribution and salt load: Equivalents ratios for different ionic components like $\mathrm{CI}^{-}, \mathrm{Mg}^{++}, \mathrm{Ca}^{++}, \mathrm{K}^{+}, \mathrm{HCO}_{3}{ }^{-}$and $\mathrm{SO}_{4}{ }^{=}$were calculated with respect to sodium by considering sodium completely from marine origin and shown in Table (2). Ratios of major sea salt components are almost constant in the seawater (Keene et al., 1986). Comparison among them reveals that ratio in rainwater are found to be higher than that of seawater values which indicates the dominance of non-marine contribution to the studied components. Results for EF shown in Table(2) revealed that all ion species were enriched which confirmed that other sources than marine mainly anthropogenic sources contributed to their levels in rainwater . As for salt load, it is possible to calculate the loads of chloride ions which reaches the land and falls on any particular area by assessing the concentration of $\mathrm{CI}^{-}(\mathrm{mg} / \mathrm{I})$ in any particular sample and the amount of rainfall $(\mathrm{mm})$. Analyses of the present data shows that loads delivered from the fallen precipitation in the urban city of Mosul was about $0.1167 \mathrm{~kg}$ CI.m ${ }^{-3}$ in rainwater delivered which equal numerically to $395 \mathrm{~kg} \mathrm{NaCI} \cdot \mathrm{h}^{-1}$ of land .

Table (2): Equivalent concentration of ionic components with respect to sodium

\begin{tabular}{|c|c|c|c|c|c|c|}
\hline \multirow{2}{*}{ Water type } & \multicolumn{7}{|c|}{ Concentration ratio } \\
\cline { 2 - 7 } & $\mathrm{CI}^{-} / \mathrm{Na}^{+}$ & $\mathrm{Ca}^{++} / \mathrm{Na}^{+}$ & $\mathrm{Mg}^{++} / \mathrm{Na}^{+}$ & $\mathrm{K}^{+} / \mathrm{Na}^{+}$ & $\mathrm{SO}_{4}{ }^{+} / \mathrm{Na}^{+}$ & $\mathrm{HCO}_{3}{ }^{-} / \mathrm{Na}^{+}$ \\
\hline Rainwater & 3.700 & 12.500 & 7.300 & 0.300 & 3.500 & 16.900 \\
\hline Seawater & 1.160 & 0.044 & 0.227 & 0.021 & 0.120 & 0.005 \\
\hline $\mathrm{EF}^{*}$ & 3.190 & 284.100 & 32.160 & 14.290 & 29.170 & 3380.000 \\
\hline \multicolumn{7}{|c|}{ Enrichment Factor . } \\
\hline
\end{tabular}

$$
\begin{aligned}
& \text { التركيب الكيميائي والحمل الملحي لمياه الأمطار في مدينة الموصل / محافظة نينوى/ العراق }
\end{aligned}
$$

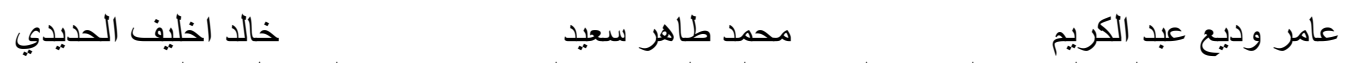

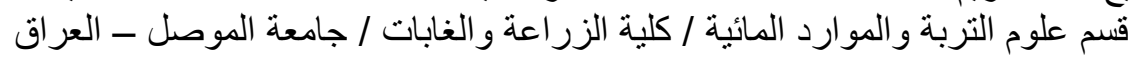

$$
\begin{aligned}
& \text { E-mail:amer-waddie@yahoo.com }
\end{aligned}
$$

\section{الخلاصة}

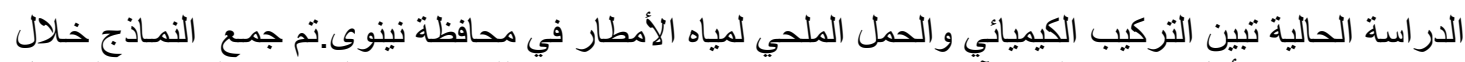

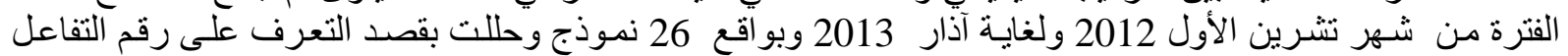
ونركيز الايونات الذائبة الرئيسية (لأئية للأمطار الساقطة في مركز المحافظة كان 338.55 ملم. بينت النتائج أن معدل الوزن ألحجمي (VWM) لكل من درجة الائة 


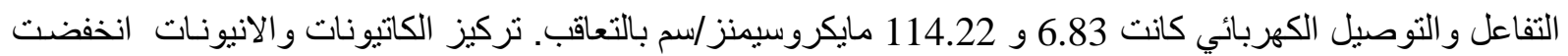

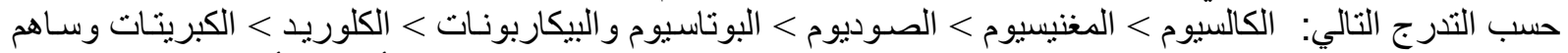

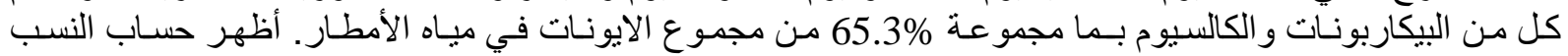

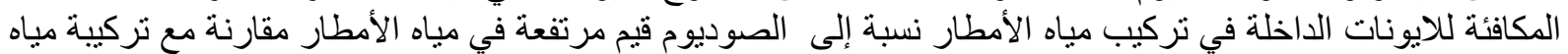

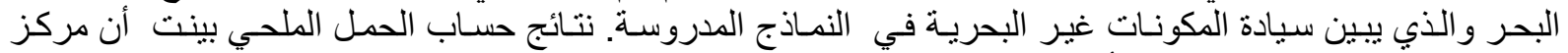

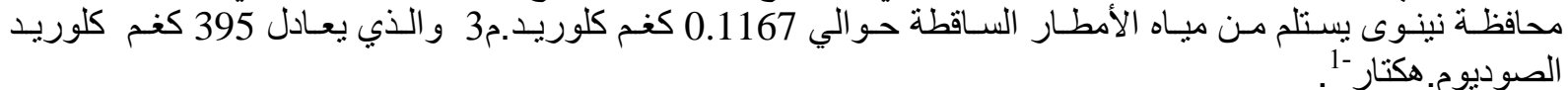
الكلمات الدالة: مباه المطر، الايصالية، رقم التفاعل، معدل الوزن ألحجمي، عامل الاغتناء. تاريخ تسلم البحث: 2013/9/3 ، وقبوله: 2014/2/17.

\section{REFERENCES}

Anonymous (1977). Regional Seminar On Reclamation and Management of Calcareous Soils. Calcareous Soils. FAO Soils Bulletin 21.

Chandra, M.P., S. V. Mohan and S.J. Reddy(2005). Rainwater chemistry at a regional representative urban site : influence of a terrestrial source on ionic composition . Atmospheric Environment .39, 999-1008.

Ghassemi, W., F. Rubio and J.I. Schroeder (1995). Salinization of Land and Water Resources . University of New South Wales Press Ltd. Canbera, Australia.

Keene,W.C., A.P. Pszenny, J.N. Galloway and M.E. Hawley.(1986).Sea salt corrections and interpretations of constituents ratios in marine precipitation. Journal of Geophysical Research, 91,6647-6658.

Kulshrestha, U.C., Kulshrestha, M.J., Sekar, R., Sastry, M, Variamani (2003). Chemical characteristics of rainwater at an urban site of south central India. Atomspheric Environment. 37, 3019-3026.

Nicolae, F. and V. Coteţ (2012). The hydrological cycle, unidirectional cycle of the dissolved salts and suspended load. Soil Forming Factors and Processes From The Temperate Zone 11, 49-56.

Oliveira, P.L.,B.R. Figueiredo and A.A. Cardoso (2012). Rainwater major and trace element contents in southeastern Brazil : an assessment of a sugar cane region in dry and wet period. Journal of Brazil Chemical Society. 23(12),2258-2265.

Radojevic, M. and V.N. Bashkin (2006). Rainwater analysis . In M. Radojevic. (ed.) Practical Environmental Analysis, $2^{\text {nd }}$ edition . 45-72. RSC Publishing.

Sillapapiromsuk, S. and S. Chantara (2010). Chemical composition and seasonal variation of acid deposition in Chiang Mai,Thailand. Environment Engineering Research . 15(2):9398.

Singh, A.S. and G.C. Mondal (2008). Chemical characterization of wet precipitation events and deposition in coal mining region, India. Journal of Atomic Chemistry, 59,1-23.

Tandon, HLS (1999). Methods of Analysis of Soils, Plants, Waters and Fertilizers. Fertilizer Development and Consultation Organization. New Delhi.

Tiwari, S. A. Ranade, D. Singh and A.K. Pandey (2006). Study of chemical species in rainwater at Ballia , a rural environment in eastern Uttar Pradesh , India. Indian Journal of Radio and Space Physics.35, 35-41.

Tolgyessy, J. (1993). Natural waters . In J. Tolgyessy (ed.) Chemistry and Biology Of Water, Air and Soil Environmental Aspects . Studies In Environmental Sciences 53. 153-182. Elsevier Science Publishers. 
Topcu, S.I. and A.T. Atimtay (2002).Chemical composition of rainwater at EMEP station in Ankara. Turkey Atomic Research,65:77-92.

Valli, M., K.S. Sree and I.V.M. Krishna. (2013). Analysis of precipitation concentration index and rainfall prediction in various agro-climatic zones of Andhra Pradesh,India. International Research Journal of Environment Sciences.2:53-61. 